\title{
Premium lamb production of South African sheep breed types under feedlot conditions
}

\author{
D.A. van der Merwe ${ }^{1}$, T.S. Brand ${ }^{1,2 \#}$ \& L.C. Hoffman ${ }^{1,3}$ \\ ${ }^{1}$ Department of Animal Sciences, Stellenbosch University, Private Bag X1, Matieland, 7602, South Africa. \\ ${ }^{2}$ Directorate: Animal Sciences, Department of Agriculture, Western Cape Government, Private Bag X1, Elsenburg, 7607, \\ South Africa. \\ ${ }^{3}$ Centre for Nutrition and Food Sciences, Queensland Alliance for Agriculture and Food Innovation (QAAFI), The \\ University of Queensland, Health and Food Sciences Precinct, 39 Kessels Road, Coopers Plains 4108, Australia.
}

(Submitted 13 February 2019; Accepted 20 August 2020; Published 24 September 2020)

Copyright resides with the authors in terms of the Creative Commons Attribution 4.0South African License.
See: http://creativecommons.org/licenses/by/4.0/zaCondition of use:
The user may copy, distribute, transmit and adapt the work, but must recognize the authors and the South African Journal of Animal
Science

\begin{abstract}
An increasing number of producers opt to finish their lambs in on-farm feedlots. Therefore, detailed production information is required to implement precision finishing of lambs of different genotypes. Precision finishing monitors growth, feed intake and efficiency to optimize management. In this study, feedlot production characteristics of Dohne Merino, Dormer, Dorper, Meatmaster, Merino, Namaqua Afrikaner, and South African Mutton Merino (SAMM) lambs were evaluated. The lambs were reared in a feedlot and fed a diet with $10.41 \mathrm{MJ}$ metabolizable energy $(\mathrm{ME}) / \mathrm{kg}$ feed and $19.06 \%$ crude protein. Feed intake and body weight were recorded weekly from an initial weight of $30 \mathrm{~kg}$ until they had the subcutaneous fat cover needed to produce an A2 carcass. Subcutaneous fat was measured on the Longissimus lumborum muscle with an ultrasound scanner. Dorper, Meatmaster and Namaqua Afrikaner had the shortest rearing periods in the feedlot, and were market ready at a lower live weight $(P<0.05)$. As a result, these lambs consumed less feed in the feedlot. Namaqua Afrikaner and Merino lambs were least efficient: 7.08 and $5.63 \mathrm{~kg} \mathrm{feed} / \mathrm{kg}$ gain, respectively. Dohne Merino, Dormer, Dorper, and Meatmaster rams and Dorper ewes were more efficient; approximately $3.58 \mathrm{~kg}$ feed $/ \mathrm{kg}$ gain. Dohne Merino and Dormer rams had the highest growth rates: approximately $465 \mathrm{~g} /$ day. The end weights described in this study could be used as an indication for producers of the ideal slaughter weights for breeds of different maturity types.
\end{abstract}

Keywords: average daily gain, fat deposition, feed efficiency, rearing period

\# Corresponding author: tersb@elsenburg.com

\section{Introduction}

Vast semi-arid and arid regions in South Africa and Namibia are unsuitable for most agricultural practices, with the exception of extensive sheep production, because sheep are well adapted to these conditions (Brand, 2000). The South African commercial sheep industry is made up of a spectrum of breeds that are classed as wool type, dual-purpose, meat type, and indigenous fat-tail, which total about 19.9 million head of sheep (DAFF, 2018). The most popular breeds in commercial production systems, based on the number of weaning weight records, are Merino, Dohne Merino and Dorper, followed by the SAMM and Dormer (Cloete \& Olivier, 2010). The Merino is regarded as a predominantly wool-type breed, whereas dualpurpose breeds are bred for wool and meat. The Dohne Merino, SAMM and the terminal sire Dormer breed were all developed from crossbreeding with the German Mutton Merino as a sire or dam line (Cloete et al., 2001; Van Wyk et al., 2003). The Dorper was developed from Dorset Horn and Blackhead Persian to obtain sheep that could survive and produce under semi-arid conditions (Milne, 2000). The Meatmaster is a more recent composite fat-tailed breed, with predominantly Damara lineage, which was developed for commercial lamb production in extensive arid conditions (Peters et al., 2010). The Namaqua Afrikaner is regarded as an unimproved indigenous fat-tailed breed with low mature weight, which tolerates harsh environmental conditions (Qwabe et al., 2013). These breeds all vary in their growth and maturity characteristics.

Because of increases in lamb and mutton prices and of pressure to intensify production systems, many producers finish their lambs in feedlots to get them market ready for slaughter. Feedlot operators aim 
to produce a carcass of optimal weight and fat cover to generate maximal income, with fat cover being a key component in the Namibian and South African carcass classification systems (Government notice No. R. 863, 2006). Feedlot operators tend to be prejudiced against finishing early maturing breeds, because they deposit fat at an earlier age and therefore have to be slaughtered at a lower live weight (Brand et al., 2018), thereby reducing the income per carcass. However, in harsher climatic regions, in which the earlier maturing Dorper, Meatmaster, and Namaqua Afrikaner are used predominantly and demand for lamb is high, operators may decide to enter these lambs in the feedlot.

From the viewpoint of a lamb producer, it is important to meet market specifications to sustain optimum profitability. According to the Red Meat Producers Organisation (2019) of South Africa, 72\% of sheep that are slaughtered in commercial abattoirs are regarded as premium lamb, with a carcass subcutaneous fat cover of $1-4 \mathrm{~mm}$ (Government notice No. R. 863, 2006), for which the highest carcass prices are obtained. But because lambs of different breeds start to deposit fat at different stages and exhibit different growth capacities, the ideal slaughter weight for each breed must be known to ensure a premium lamb carcass. To ensure carcass quality, ultrasound technology may be implemented to determine the subcutaneous fat cover (Houghton \& Turlington, 1992) - as was done in this study - instead of using bodyweight, rearing length and subjective measurements to determine when lambs are suitable for slaughter. Information about the rearing characteristics of various breeds and conditions could be compiled in decision-support systems and feedlot calculators so that accurate simulations could be performed to determine the most profitable production protocol.

The feedlot production characteristics of Dormer, Meatmaster and Namaqua Afrikaner lambs have not been described in the literature. Thus, the aim of this study was to compare the feedlot production characteristics of ewe and ram lambs of seven South African sheep breeds up to the ideal slaughter weight as determined by the desired level of fat cover.

\section{Materials and Methods}

The experimental procedures were approved by the Departmental Ethics Committee of Research on Animals (DECRA 14/110) of Western Cape Department of Agriculture. This study investigated the feedlot production characteristics of ram and ewe lambs of seven breeds to reach a slaughter weight with ideal fat cover. These breeds were the Dohne Merino $(\mathrm{ewe}=10$, ram $=6)$, Dormer $(\mathrm{ewe}=5$, ram $=5)$, Dorper $(\mathrm{ewe}=$ 6 , ram $=8$ ), Meatmaster (ewe $=12$, ram $=12$ ), Merino $(\mathrm{ewe}=6$, ram $=6)$, Namaqua Afrikaner $(\mathrm{ewe}=8$, ram $=6$ ), and SAMM (ewe $=4$, ram =6). Lambs were obtained from the same resource flocks, and were herded under the same conditions. These flocks are kept on Langgewens Research Farm of the Western Cape Department of Agriculture in the Swartland district (coordinates 33.276833, 18.704252). The ewes were maintained on cereal stubble and medic pastures (Medicago truncutula, Medicago littoralis and Medicago polymorpha). The ewes were synchronized and mated with rams from their own breeds. Lambing occurred during the wet winter months of May - June. Lambs had ad libitum access to creep feed before weaning, namely $86.9 \%$ total digestible nutrients, $18.2 \%$ crude protein, $13.5 \%$ fat, $8.4 \%$ crude fibre, $1.12 \%$ calcium, and $0.74 \%$ total phosphorous. The tails of the Dohne Merino, Dormer, Dorper, Merino and SAMM lambs were docked at two weeks old, whereas those of the Meatmaster and Namaqua Afrikaner were left intact, as in commercial practice. The lambs were weighed weekly. Average daily gains (ADG) was calculated as the difference between the final and initial measurements of the feeding period divided by the number of days in the feedlot.

For this trial, the lambs were weaned as they attained a bodyweight of $30 \mathrm{~kg}$. However, because Namaqua Afrikaner sheep have a lower mature bodyweight and grow at a slower rate, these lambs were weaned at an average weight of $27.7 \mathrm{~kg} \pm 0.50$. The average starting weight of the lambs from the other breeds was $30.6 \mathrm{~kg} \pm 0.20$. The lambs were housed in individual pens $(1 \mathrm{~m} \times 2 \mathrm{~m})$ at Elsenburg Research Farm of Western Cape Department of Agriculture to monitor individual growth and feed intake. On introduction to the feedlot, they were drenched against internal parasites, and for the first three days they were dosed with $0.1 \mathrm{~g}$ virginiamycin to help them to adapt to the concentrate diet. The lambs were adapted gradually from a hay ration to a pelleted concentrate diet over seven days. They were then supplied with the feedlot concentrate diet ad libitum, with feed bunks being topped up daily in the mornings and afternoons. Lambs had free access to water during the feeding period. The composition of the feedlot diet is presented in Table 1. Feed refusals were weighed back at the same time each week to determine weekly feed intake. Daily feed intake (DFI) was determined by dividing the cumulative intake over the test period by the number of days on feed. Feed conversion ratio (FCR) was calculated by dividing DFI by the ADG.

Back-fat thickness was assessed with a Mindray DP30V ultrasound scanner (Shenzhen Mindray Biomedical Electronics Co., Ltd.) with a $7.5 \mathrm{MHz}$ linear transducer. Ultrasound measurements were taken on the subcutaneous fat of the left Longissimus lumborum muscle at the 13th rib and between the 3rd and 4th lumbar vertebrae (rump) at the midpoint of the transverse muscle. At scanning, the wool or hair at these 
positions was combed to provide a scanning area for the transducer. The lambs were reared under these feeding conditions until they achieved a subcutaneous fat thickness that indicated they had attained a carcass fat score of 2 (Government notice No. R. 863, 2006). The relationship between the ultrasound measurement and carcass fat depth of Van der Merwe et al. (2019a) implies an ultrasound measurement of $0.52 \mathrm{~cm}$ is required to attain a carcass fat score of 2 with a subcutaneous depth on the carcass of $4 \mathrm{~mm}$. Therefore, lambs were deemed to be slaughter ready and removed from the feedlot when back-fat measurements of $5.2 \pm 0.5 \mathrm{~mm}$ were recorded using ultrasound. The average daily gain in fat depth was calculated as the difference between initial and final measurements, divided by the number days in the feedlot.

Table 1 Ingredient formulation and nutritional composition of the feedlot diet fed to lambs from approximately $30 \mathrm{~kg}$ live weight until they attained a sufficient fat depth to have an A2 carcass

\begin{tabular}{lc}
\hline Ingredient & $\begin{array}{c}\text { Inclusion } \\
\text { (\% as fed) }\end{array}$ \\
\hline Maize & 50.00 \\
Lucerne hay & 36.00 \\
Cottonseed oilcake & 6.00 \\
Molasses powder & 2.50 \\
Ammonium chloride & 0.50 \\
Ammonium sulphate & 0.50 \\
Feed lime & 0.50 \\
Monocalcium phosphate & 0.50 \\
Common salt & 1.00 \\
Urea & 0.50 \\
Sodium bicarbonate & 1.00 \\
Slaked lime & 0.50 \\
Sulphur & 0.20 \\
Vitamin and mineral premix & 0.15 \\
Commercial growth promoters and coccidiostat premix* & 0.12 \\
Nutrient composition & \\
Dry matter, \% & 90.15 \\
Calculated total digestible nutrients, \% & 69.43 \\
Metabolizable energy, MJ/kg & 10.41 \\
Calculated nitrogen free extract, \% & 39.36 \\
Crude protein, \% & 19.06 \\
Calculated rumen undegradable protein, \% & 4.30 \\
Crude fibre, \% & 15.22 \\
Neutral detergent fibre, \% & 23.79 \\
Acid detergent fibre, \% & 17.02 \\
Ash, \% & 10.23 \\
Fat, \% & 6.26 \\
Phosphorous, \% & 1.39 \\
& 0.43 \\
\hline
\end{tabular}

${ }^{*}$ Premix contained Stafac, Selinomycin and Taurotec

The data were analysed with analysis of variance using PROC GLM of SAS (SAS Institute Inc., Cary, North Carolina, USA). The main effects of sex and breed their interaction were evaluated. Effects were considered significant when $P \leq 0.05$. The least square means for the main effects and their standard errors 
are tabulated. For most of the data, significant interactions between breed and sex were not observed. Differences among the means were evaluated with the Bonferroni test at $5 \%$ significance level.

\section{Results and Discussion}

The feedlot production characteristics of the lambs from the various breeds are presented in Table 2 . Because these breeds grow at different rates, the ages of the groups varied $(P<0.05)$ at which they were introduced to the feedlot at the bodyweight of $30 \mathrm{~kg}$. Ewe lambs were older upon entry into the feedlot than ram lambs $(P<0.05)$. Namaqua Afrikaner lambs were very much older than the other breeds when they entered the feedlot, despite weighing less. Although the length of the feeding period generally did not differ between ewe and ram lambs $(P=0.574)$, Namaqua Afrikaner ewe lambs spent a longer time in the feedlot than the corresponding ram lambs (39 and 18 days, respectively) $(P<0.05)$. Merino lambs were fed for the longest time, but the time on feed for Dohne Merino, SAMM, Dormer required a similar time on feed to produce an A2 carcass. Dorper and Meatmaster lambs required less time on feed $(P<0.05)$. Namaqua Afrikaner ewes were projected to be slaughter-ready at a heavier weight than their sibling rams $(32.9 \mathrm{~kg}$ vs. $30.6 \mathrm{~kg})(P<0.05)$. However, the overall end weights of ewe lambs were $9 \%$ lower than those of ram lambs $(P<0.05)$. South African Mutton Merino, Dohne Merino, and Dormer lambs were heaviest when they attained the projected A2 carcass endpoint, followed by Merino, Dorper, Meatmaster, and finally Namaqua Afrikaner $(P<0.05)$. Ewe lambs from Dormer and Namaqua Afrikaner had higher cumulative feed intake $(51.3 \mathrm{~kg}$ and $40.4 \mathrm{~kg}$, respectively) than ram lambs $(46.1 \mathrm{~kg}$ and $18.8 \mathrm{~kg}$, respectively). Whereas the general trend was for the cumulative intake of ewe lambs to be $13 \%$ lower than for ram lambs. Despite spending a similar amount of time on feed, the Dormer lambs ate more both per day and cumulatively, grew faster and were more efficient than the Namaqua Afrikaner lambs. The breeds with the highest cumulative intakes were Merino, Dohne Merino and SAMM, followed by Dormer, Dorper, and Namaqua Afrikaner, with the Meatmaster lambs having the least cumulative intake, because they reached the slaughter-ready endpoint soonest.

The DFI intake of ewe lambs was $6 \%$ lower than that of ram lambs $(P=0.08)$, whereas the DFI of Dohne Merino, Dormer, Merino and SAMM ( 1533 g/day) was significantly higher than that of Meatmaster and Namaqua Afrikaner lambs ( 1150 g/day). The daily intake of Dorper lambs (1245.6 g/day) did not differ from the other breeds $(P>0.05)$. Dormer lambs had the highest ADG which was significantly greater than Merino and Namaqua Afrikaner lambs. The growth rates of Dohne Merino, Dorper), Meatmaster and SAMM differed only from those of Namaqua Afrikaner lambs $(P<0.05)$. The growth rate of ewe lambs was on average $24 \%$ lower than that of ram lambs $(P<0.05)$. As a consequence of the differences in DFI and ADG, FCR was $23 \%$ higher for ewe lambs than for ram lambs $(P=0.003)$. The Namaqua Afrikaner lambs were less $(P<0.05)$ efficient than Dohne Merino, Dormer, Dorper, Meatmaster and SAMM lambs, which did not differ from each other. The slightly higher FCR of Merino lambs (5.63 kg feed/ weight gain) did not differ from that of any of the other breeds $(P>0.05)$.

Ultrasound fat depth measurements are shown in Table 3. Because a fat depth of $\sim 5.2 \mathrm{~mm}$ was the basis for identifying lambs as slaughter ready, the end fat depths measured at the rump region did not differ $(P>0.05)$. At the start of the feeding period, ewe lambs had greater fat depths over the 13th rib and rump than ram lambs $(P<0.05)$. Similar trends were observed for breeds at the start of the trial, with Meatmaster lambs being fatter than Dohne Merino, Dormer, Namaqua, and Afrikaner lambs at the 13th rib $(P<0.05)$. The initial rump fat of Meatmaster lambs was greater $(P<0.05)$ from all the other breeds except for the Dorper, which also did not differ from the other breeds $(P>0.05)$. Although the fat depths at the rump at the end of the rearing period did not differ $(P>0.05)$ between the breeds (Table 3), the depths at the 13th rib differed significantly. The highest back-fat depths were recorded by SAMM and Merino lambs, which differed $(P$ $<0.05)$ from those of Namaqua Afrikaner lambs $(3.1 \mathrm{~mm})$. The fat depth of the remaining breeds, however, did not differ from any of the other breeds, with an average depth of $3.7 \mathrm{~mm}$ at the 13th rib.

The fat deposition rate was calculated as the initial fat depth subtracted from final fat depth divided by the length of the feeding period. The fat deposition rate at the 13th rib did not differ between ewes and rams or between breeds $(P>0.05)$, with an average rate of $0.04 \mathrm{~mm} /$ day, No differences in fat deposition rate were observed between ewe and ram lambs $(P>0.05)$ at the rump measurement site However, the rate of fat deposition in Meatmaster lambs was significantly higher than that of Dohne Merino and Merino lambs. The fat deposition rates of the remaining breeds did not differ from the other breeds with an average rate of $0.08 \mathrm{~mm} /$ day. 
Table 2 Feedlot production characteristics of ewe and ram lambs of seven South African sheep breeds, from initial bodyweight of $30.6 \mathrm{~kg}(27.7 \mathrm{~kg}$ for Namaqua Afrikaner lambs) to produce a carcass with ideal fat cover

\begin{tabular}{|c|c|c|c|c|c|c|c|c|}
\hline & Main effect & $\begin{array}{c}\text { Initial age, } \\
\text { days }\end{array}$ & $\begin{array}{c}\text { Days on feed, } \\
\text { days }\end{array}$ & $\begin{array}{c}\text { End weight, } \\
\mathrm{kg}\end{array}$ & $\begin{array}{c}\text { Cumulative } \\
\text { intake, } \mathrm{kg}\end{array}$ & $\begin{array}{c}\text { Average daily gain, } \\
\text { g/day }\end{array}$ & $\begin{array}{c}\text { Daily feed intake, } \\
\text { g/day }\end{array}$ & $\begin{array}{c}\text { Feed conversior } \\
\text { ratio, } \mathrm{kg} / \mathrm{kg}\end{array}$ \\
\hline \multirow[t]{3}{*}{ Sex } & Ewe & $100 \pm 2.6$ & $31 \pm 1.4$ & $38.5 \pm 0.50$ & $41.6 \pm 2.26$ & $279.4 \pm 15.29$ & $1340.2 \pm 37.74$ & $5.33 \pm 0.269$ \\
\hline & Ram & $88 \pm 2.5$ & $32 \pm 1.4$ & $42.3 \pm 0.49$ & $47.6 \pm 2.25$ & $368.9 \pm 15.70$ & $1425.0 \pm 37.45$ & $4.32 \pm 0.272$ \\
\hline & $P$-value & $<0.001$ & 0.574 & $<0.001$ & 0.043 & $<0.001$ & 0.080 & 0.003 \\
\hline \multirow[t]{8}{*}{ Breed } & Dohne Merino & $86^{b c} \pm 4.4$ & $39^{\mathrm{ab}} \pm 2.5$ & $44.5^{a} \pm 0.86$ & $58.1^{\mathrm{a}} \pm 3.91$ & $352.3^{\mathrm{ab}} \pm 26.36$ & $1506.6^{\mathrm{a}} \pm 65.29$ & $4.61^{b} \pm 0.457$ \\
\hline & Dormer & $74^{c} \pm 5.4$ & $32^{\mathrm{abc}} \pm 3.0$ & $44.0^{a} \pm 1.05$ & $48.7^{\mathrm{ab}} \pm 4.79$ & $438.6^{a} \pm 32.28$ & $1529.5^{a} \pm 79.96$ & $3.71^{b} \pm 0.560$ \\
\hline & Dorper & $89^{b c} \pm 4.6$ & $26^{\mathrm{C}} \pm 2.6$ & $39.4^{b} \pm 0.90$ & $32.1^{b c} \pm 4.09$ & $327.3^{\mathrm{ab}} \pm 27.57$ & $1245.6^{\mathrm{ab}} \pm 68.28$ & $3.71^{b} \pm 0.505$ \\
\hline & Meatmaster & $101^{b} \pm 3.5$ & $15^{d} \pm 1.9$ & $35.2^{c} \pm 0.68$ & $19.5^{c} \pm 3.09$ & $334.0^{\mathrm{ab}} \pm 21.31$ & $1228.2^{b} \pm 51.61$ & $4.57^{b} \pm 0.369$ \\
\hline & Merino & $91^{\mathrm{bc}} \pm 4.9$ & $43^{a} \pm 2.7$ & $42.7^{\mathrm{ab}} \pm 0.96$ & $67.1^{\mathrm{a}} \pm 4.38$ & $283.5^{b c} \pm 29.47$ & $1540.1^{a} \pm 72.99$ & $5.63^{\mathrm{ab}} \pm 0.511$ \\
\hline & Namaqua Afrikaner & $145^{a} \pm 4.6$ & $28^{b c} \pm 2.6$ & $31.7^{c} \pm 0.90$ & $29.6^{b c} \pm 4.09$ & $168.6^{c} \pm 31.26$ & $1070.6^{b} \pm 68.28$ & $7.08^{a} \pm 0.542$ \\
\hline & SAMM & $71^{c} \pm 5.5$ & $37^{\mathrm{abc}} \pm 3.1$ & $44.8^{a} \pm 1.07$ & $57.1^{a} \pm 4.89$ & $365.0^{\mathrm{ab}} \pm 32.95$ & $1554.1^{a} \pm 81.61$ & $4.46^{b} \pm 0.571$ \\
\hline & $P$-value & $<0.001$ & $<0.001$ & $<0.001$ & $<0.001$ & $<0.001$ & $<0.001$ & $<0.001$ \\
\hline
\end{tabular}

${ }^{a-b}$ Within a column, means with a common superscript do not differ at $P=0.05$; SAMM: South African Mutton Merino 
Table 3 Ultrasound back-fat depth measurements at 13th rib and between 3rd and 4th lumbar vertebrae at start and end of finishing periods of ewe and ram lambs of seven South African sheep

\begin{tabular}{|c|c|c|c|c|c|c|c|}
\hline & \multirow[b]{2}{*}{ Main effect } & \multicolumn{3}{|c|}{ Fat cover at 13th rib } & \multicolumn{3}{|c|}{ Fat cover over rump } \\
\hline & & Initial, mm & End, mm & $\begin{array}{c}\text { deposition rate, } \\
\mathrm{mm} / \text { day }\end{array}$ & Initial, mm & End, mm & $\begin{array}{c}\text { deposition rate, } \\
\mathrm{mm} / \text { day }\end{array}$ \\
\hline \multirow[t]{3}{*}{ Sex } & Ewe & $2.9 \pm 0.08$ & $3.9 \pm 0.12$ & $0.04 \pm 0.007$ & $3.1 \pm 0.09$ & $5.0 \pm 0.08$ & $0.07 \pm 0.007$ \\
\hline & Ram & $2.4 \pm 0.08$ & $3.7 \pm 0.12$ & $0.05 \pm 0.007$ & $2.8 \pm 0.09$ & $5.1 \pm 0.08$ & $0.09 \pm 0.007$ \\
\hline & $P$-value & $<0.001$ & 0.219 & 0.341 & 0.020 & 0.184 & 0.106 \\
\hline \multirow[t]{8}{*}{ Breed } & Dohne Merino & $2.5^{b} \pm 0.15$ & $3.6^{\mathrm{ab}} \pm 0.21$ & $0.03 \pm 0.013$ & $2.7^{b} \pm 0.15$ & $4.8 \pm 0.14$ & $0.06^{b} \pm 0.012$ \\
\hline & Dormer & $2.4^{b} \pm 0.18$ & $3.9^{\mathrm{ab}} \pm 0.25$ & $0.05 \pm 0.016$ & $2.8^{\mathrm{b}} \pm 0.19$ & $5.1 \pm 0.17$ & $0.07^{\mathrm{ab}} \pm 0.015$ \\
\hline & Dorper & $2.8^{\mathrm{ab}} \pm 0.15$ & $3.5^{\mathrm{ab}} \pm 0.22$ & $0.03 \pm 0.013$ & $3.3^{\mathrm{ab}} \pm 0.16$ & $5.1 \pm 0.14$ & $0.08^{\mathrm{ab}} \pm 0.013$ \\
\hline & Meatmaster & $3.1^{\mathrm{a}} \pm 0.12$ & $3.9^{\mathrm{ab}} \pm 0.16$ & $0.06 \pm 0.010$ & $3.7^{\mathrm{a}} \pm 0.12$ & $5.3 \pm 0.11$ & $0.12^{a} \pm 0.010$ \\
\hline & Merino & $2.7^{\mathrm{ab}} \pm 0.16$ & $4.2^{\mathrm{a}} \pm 0.23$ & $0.04 \pm 0.014$ & $3.0^{b} \pm 0.17$ & $4.9 \pm 0.15$ & $0.05^{\mathrm{b}} \pm 0.014$ \\
\hline & Namaqua Afrikaner & $2.1^{b} \pm 0.15$ & $3.1^{b} \pm 0.22$ & $0.04 \pm 0.013$ & $2.6^{b} \pm 0.17$ & $5.1 \pm 0.14$ & $0.10^{a b} \pm 0.013$ \\
\hline & SAMM & $2.7^{\mathrm{ab}} \pm 0.18$ & $4.4^{\mathrm{a}} \pm 0.26$ & $0.05 \pm 0.016$ & $2.6^{b} \pm 0.20$ & $4.9 \pm 0.17$ & $0.07^{a b} \pm 0.015$ \\
\hline & $P$-value & $<0.001$ & 0.005 & 0.463 & $<0.001$ & 0.206 & $<0.001$ \\
\hline
\end{tabular}

${ }^{\mathrm{a}-\mathrm{b}}$ Within a column, means with a common superscript do not differ at $P=0.05$; SAMM: South African Mutton Merino 
Feedlot finishing uses the high growth rates of young animals advantageously to rear them from a light bodyweight with low market value to a heavier bodyweight that would yield a desirable carcass. This added value is achieved by feeding concentrated rations to promote muscle growth and fat deposition to enhance the dressing percentage of the carcass and improve carcass quality. Feedlot finishing also allows for compensatory growth to occur in lambs that experienced restricted nutrition, which enhances their feeding efficiency (Shadnoush et al., 2011). Early maturing breeds have a shorter rearing period in the feedlot resulting from their earlier onset of fat deposition. Thus, they are marketed at lower slaughter weights to produce a carcass with the same fat cover (Strydom et al., 2008). This results in a lower proportion of weight that can be gained in the feedlot and therefore a lower return on investment.

The main considerations when rearing lambs include growth rate, maturity type and production efficiency. The frame size and mature weight of an animal are often related to maturity and fat deposition, with animals with a lower mature weight and frame size being early maturing (Owens et al., 1993). For example, ewe lambs have a lower mature weight than ram lambs (Butterfield, 1988; Van der Merwe et al., 2019b). The Namaqua Afrikaner and Meatmaster breeds have small frame sizes. Dorper sheep, however, seem to be the exception as they mature early, yet attain relatively higher mature weights (Cloete et al., 2000). Fat-tailed Damara (a precursor to the Meatmaster) lambs with lower carcass weights than Dorper lambs had similar levels of subcutaneous fat (Tshabalala et al., 2003). This suggests that fat-tailed breeds are early maturing and may mature even earlier than the Dorper. Another consideration is the protein deposition rate, which increases with available nutrients until a maximum is reached and then excess nutrients are deposited as fat (Gerrits et al., 1996). Siebrits et al. (1986) showed that protein deposition in animals was related to the pattern of feed intake, and that lean pigs had higher protein deposition peaks, which occurred at a later stage than in obese pigs. This demonstrated that later maturing breeds, which usually have higher mature weight (Owens et al., 1993) would exhibit higher growth rates and would finish later than early maturing breeds, where fat deposition occurs earlier. The principle of relating growth rate and mature weight to maturity may be confounded by wool breeds such as Dohne Merino and Merino ewes, which have lower mature weights (Van der Merwe et al., 2019b) and do not exhibit high levels of fat deposition compared with other early maturing breeds. This may be due to partitioning nutrients to wool production rather than to carcass tissue deposition (Adams \& Liu, 2003).

Differences between the breeds may also differences in fat deposition. Ram lambs grow at a faster rate than ewe lambs, whereas ewe lambs tend to attain maturity at a lower live weight than intact ram lambs (Butterfield, 1988). Therefore ewes show higher levels of fat deposition than ram lambs at the same live weight. Ewe lambs had greater fat depths when they entered the feedlot, but fat deposition occurred at a similar rate in both sexes under an 'ideal' nutritional environment (Table 3). Johnson et al. (2005) confirmed that ewe lambs had greater subcutaneous fat depths than ram lambs when slaughtered at a common bodyweight. Intact rams also presented higher growth rates and were leaner than castrated lambs at slaughter (Schanbacher et al., 1980), whereas the fat depths of ewe lambs and wethers were similar when slaughtered at the same live weight (Dimsoski et al., 1999).

Brand et al. (2018) found higher rates of fat deposition in Dorper lambs than in SAMM lambs, which were in turn higher than those of Merino lambs. Cloete et al. (2012) observed that the subcutaneous fat depths of Dormer and SAMM carcasses were greater than those of Dohne Merino and Merino carcasses. In an earlier study, it was observed that the subcutaneous fat depth of Dormer carcasses was greater than that of SAMM carcasses (Cloete et al., 2004). It can thus be assumed that fat-tailed breeds mature earlier than Dorper, followed by the Dormer and SAMM, and the Dohne Merino and Merino are later maturing. This study showed that subcutaneous fat deposition occurred at the same rate in all breeds, except Meatmaster and Namaqua Afrikaner, during the finishing period directly after weaning $(0.04 \mathrm{~mm} /$ day and $0.07 \mathrm{~mm} /$ day at the 13th rib and rump, respectively) (Table 3). However, the onset of fat accretion governs physiological maturity. Therefore, the fat-tailed breeds that show higher rates of fat deposition and store fat in their rump region are presumably early maturing (Negussie et al., 2003).

Early maturing breeds, in particular the Meatmaster and Namaqua Afrikaner and the Dorper, were thus fed for shorter periods to attain market-readiness at lighter weights (Table 2). High growth rates were attained by Dormer, SAMM, Dohne Merino, Meatmaster, and Dorper lambs, with Dormer lambs demonstrating exceptionally high growth rates in the feedlot. Dohne Merino, Dormer and SAMM lambs could then be marketed for slaughter at heavier end weights with 30 - 40 days of feeding. The feed efficiency of most of the breeds in the feedlot proved favourable, apart from Merino and Namaqua Afrikaner lambs. The Merino presents a lower growth rate and therefore has to be reared for longer, consuming more feed, and reducing feed efficiency. The indigenous Namaqua Afrikaner lambs presented the most unfavourable feedlot production characteristics. Owing to the early maturing nature of the breed and the high level of fat deposition in the tail (Negussie et al., 2003), Namaqua Afrikaner sheep would have greater energy requirements for growth at this bodyweight range (>30 kg bodyweight). 
The DFI in Namaqua Afrikaner, Meatmaster and Dorper tended to be lower than the other breeds. This might be because of their smaller frame, although this could be ascribed to the higher levels of adipose tissue, particularly in the tail. Leptin hormones are secreted by these adipose tissues, which regulate appetite stimulating or suppression mechanisms and thus intake, depending on the blood leptin concentrations (Pulina et al., 2013). It is thus theorized that the breeds that start to deposit fat at an earlier age and lighter weight have slightly elevated blood leptin levels compared with the other breeds, resulting in decreased appetite for a high concentrate ration. Further research may be required to prove this hypothesis. It may be necessary to apply different feeding regimes for finishing slaughter lambs, in particular for early maturing breeds. For example, indigenous breeds that are reared in extensive conditions utilize roughage better than improved breeds (Sheridan et al., 2003). For more cost efficient production, lower energy density diets could be used to rear early maturing breeds while retarding fat deposition. Because the rearing periods of these breeds are shorter, along with lower daily intakes, they have lower cumulative feed intakes than the other later maturing breeds, particularly the Meatmaster. Therefore, these fat-tailed breeds and the Dorper can be reared to an ideal slaughter weight to produce a carcass with the desired level of fat cover, with less feed. However, a smaller carcass would then be obtained at slaughter.

Brand et al. (2017) found that finishing periods of 42 days were sufficient to produce the desired carcass from Merino and SAMM lambs and 21 days for Dorper lambs. This coincides with the findings of the current study. Brand et al. (2017) reported higher intake and FCR for SAMM and Dorper than those observed in this study. However, the diet in that study had a lower energy and protein content than that of the current study $(9.41 \mathrm{MJ} \mathrm{ME} / \mathrm{kg}$ feed and $16.0 \%$ crude protein as opposed to $10.41 \mathrm{MJ} \mathrm{ME} / \mathrm{kg}$ feed and $19.1 \%$ crude protein) which accounts for these differences. Terblanche (2013) reported that Dohne Merino rams weaned at $36.5 \mathrm{~kg}$ with an ADG of $0.426 \mathrm{~kg} /$ day should be reared for 25 days in the feedlot, whereas ewe lambs weaned at $33.9 \mathrm{~kg}$ with a growth rate of $0.289 \mathrm{~kg} /$ day should be reared for 45 days.

It was evident that the growth rate and maturity of lambs from different genotypes varied and therefore different management strategies and rearing periods should be implemented, particularly if placement of lambs in a feedlot is deemed an option to achieve the desired product. The breeds in this study showed acceptable growth rates and feeding efficiencies for commercial feedlot finishing, particularly the Dormer lambs, but with the exception of the Namaqua Afrikaner.

The onset of fat deposition influenced the rearing periods and marketing weight of lambs. The use of ultrasound technology to monitor fat deposition proved valuable in determining the optimal point of slaughter (Hopkins et al., 1996). This is the first study to use ultrasound technology to select animals for slaughter based on subcutaneous fat cover. However, the implementation of ultrasound technology in lamb rearing may not be feasible because of the additional costs of equipment, training a technician, and labour. Until this technology is implemented in the feedlot industry, the market end weights from this study could be used as a guideline for finishing lambs of the various breeds.

\section{Conclusion}

To produce lambs with the ideal carcass classification according to South African standards, different rearing strategies are necessary for the various sheep breeds. The variations in maturity and the onset of fat deposition account for the differences in the rearing periods that are required to produce a carcass meeting the A2 specification. At an average lamb to feed price ratio of 8 to 1 and feed costs accounting for $75 \%$ of feedlot production costs, it would be feasible to finish all of the breeds in this study in a feedlot with the exception of the Namaqua Afrikaner. Further research may be needed to examine ways to retard fat deposition in the early maturing breeds such as Dorper, Meatmaster, and Namaqua Afrikaner, including use of less energy-dense rations for finishing them.

\section{Acknowledgments}

The authors wish to thank the Western Cape Department of Agriculture for the use of their facilities to conduct the study, and Western Cape Agricultural Research Trust, Cape Wools South Africa and National Research Foundation of South Africa (RTF150512117948) for funding the project.

\section{Authors' contribution}

DAVdM collected and analysed the data, interpreted the results, and wrote the initial draft of the manuscript; TSB conceptualized the hypothesis and design of the trials and collaborated in the interpretation of the results; LCH collaborated in the interpretation of the results and critical review of the manuscript. All authors read and approved the final manuscript.

\section{Conflict of Interest Declaration}

The authors declare that they have no conflicts of interest associated with this study. 


\section{References}

Adams, N.R. \& Liu, S.M., 2003. Principles of nutrient partitioning for wool, growth and reproduction: Implications for nematode parasitism. Aust. J. Exp. Agric., 43, 1399-1407. https://doi.org/10.1071/EA03007

Brand, T.S., 2000. Grazing behaviour and diet selection by Dorper sheep. Small Rumin. Res., 36, $147-158$. https://doi.org/10.1016/S0921-4488(99)00158-3

Brand, T.S. \& Franck, F., 2000. Production responses of two genetic different types of Merino sheep subjected to different nutritional levels. Small Rumin. Res., 37, 85-91. https://doi.org/10.1016/S0921-4488(99)00126-1

Brand, T.S., Van der Westhuizen, E.J., Van der Merwe, D.A. \& Hoffman. L.C., 2017. Effect of days in feedlot on growth performance and carcass characteristics of Merino, South African Mutton Merino and Dorper lambs. S. Afr. J. Anim. Sci. 47, 26-33. http://dx.doi.org/10.4314/sajas.v47i1.5

Brand, T.S., Van der Westhuizen, E.J., Van der Merwe, D.A. \& Hoffman, L.C., 2018. Analysis of carcass characteristics and fat deposition of Merino, South African Mutton Merino and Dorper lambs housed in a feedlot. S. Afr. J. Anim. Sci., 48, 477-488. http://dx.doi.org/10.4314/sajas.v48i3.8

Butterfield, R.M., 1988. New concept of sheep growth. The Department of Veterinary Anatomy, University of Sydney. pp. 1-33.

Cloete, J.J.E., Hoffman, L.C. \& Cloete, S.W.P., 2012. A comparison between slaughter traits and meat quality of various sheep breeds: Wool, dual-purpose and mutton. Meat Sci., 91, 318-324. https://doi.org/10.1016/j.meatsci.2012.02.010

Cloete, J.J.E., Hoffman, L.C., Cloete, S.W.P. \& Fourie, J.E., 2004. A comparison between the body composition, carcass characteristics and retail cuts of South African Mutton Merino and Dormer sheep. S. Afr. J. Anim. Sci., 34, 44-51.

Cloete, S.W.P. \& Olivier, J.J., 2010. South African Industry. In: D.J. Cottle (ed). The international sheep and wool handbook. Nottingham University Press, Nottingham. England. Pp. 95-112.

Cloete, S.W.P., Snyman, M.A. \& Herselman, M.J., 2000. Productive performance of Dorper sheep. Small Rumin. Res., 36, 119-135. https://doi.org/10.1016/S0921-4488(99)00156-X

Cloete, S.W.P., Schoeman, S.J., Coetzee, J. \& Morris, J.D.V., 2001. Genetic variances for liveweight and fleece traits in Merino, Dohne Merino and South African Meat Merino sheep. Aust. J. Exp. Agric., 41, 145-153. https://doi.org/10.1071/EA00030

Department of Agriculture, Forestry and Fisheries, 2018. Abstract of Agricultural statistics. DAFF: Directorate statistics and economic analysis, South $\quad$ Africa. https://www.daff.gov.za/Daffweb3/Portals/0/Statistics\%20and\%20Economic\%20Analysis/Statistical\%20Informatio n/Abstract\%202018.pdf

Dimsoski, P., Tosh, J.J., Clay, J.C. \& Irvin, K.M., 1999. Influence of management system on litter size, lamb growth, and carcass characteristics in sheep. J. Anim. Sci., 77, 1037-1043. https://doi.org/10.2527/1999.7751037x

Erasmus, L.J., Botha, P.M., Cruywagen, C.W. \& Meissner, H.H., 1994. Amino acid profile and intestinal digestibility in dairy cows of rumen-undegradable protein from various feedstuffs. J. Dairy Sci., 77, 541-551. https://doi.org/10.3168/jds.S0022-0302(94)76982-4

Gerrits, W.J., Tolman, G.H., Schrama, J.W., Tamminga, S., Bosch, M.W. \& Verstegen, M.W., 1996. Effect of protein and protein-free energy intake on protein and fat deposition rates in preruminant calves of 80 to $240 \mathrm{~kg}$ live weight. J. Anim. Sci., 74, 2129-2139. https://doi.org/10.2527/1996.7492129x

Government Notice No. R. 863 of 1 September 2006. Agricultural product standards Act 119 of 1990. Regulations regarding the classification and marketing of meat in the Republic of South Africa.

Hopkins, D.L., Hall, D.G. \& Luff, A.F., 1996. Lamb carcass. 3. Describing changes in carcasses of growing lambs using real-time ultrasound and the use of these measurements for estimating the yield of saleable meat. Aust. J. Exp. Agric., 36, 37-43. https://doi.org/10.1071/EA9960037

Houghton, P.L. \& Turlington, L.M., 1992. Application of ultrasound for feeding and finishing animals: A review. J. Anim. Sci., 70, 930-941. https://doi.org/10.2527/1992.703930x

Johnson, P.L., Purchas, R.W., McEwan, J.C. \& Blair, H.T., 2005. Carcass composition and meat quality differences between pasture-reared ewe and ram lambs. Meat Sci., 71, 383-391. https://doi.org/10.1016/j.meatsci.2005.04.021

Kempster, A.J., 1981. Fat partition and distribution in the carcasses of cattle, sheep and pigs: a review. Meat Sci., 5, 8398. https://doi.org/10.1016/0309-1740(81)90007-3

Lawrence, T.L.J., Fowler, V.R. \& Novakofksi J.E., 2012. Growth of farm animals. Second edition. CABI, Wallingford, Oxfordshire, England. Pp. 216-228.

Milne, C., 2000. The history of the Dorper sheep. Small Rumin. Res., 36, 99-102. https://doi.org/10.1016/S09214488(99)00154-6

Negussie, E., Rottmann, O.J., Pirchner, F. \& Rege, J.E.O., 2003. Patterns of growth and partitioning of fat depots in tropical fat-tailed Menz and Horro sheep breeds. Meat Sci., 64, 491-498. https://doi.org/10.1016/S03091740(02)00227-9

Owens, F.N., Dubeski, P. \& Hanson, C.F., 1993. Factors that alter the growth and development of ruminants. J. Anim. Sci., 71, 3138-3150. https://doi.org/10.2527/1993.71113138x

Peters, F.W., Kotze, A., Van der Bank, F.H., Soma, P. \& Grobler, J.P., 2010. Genetic profile of the locally developed Meatmaster sheep breed in South Africa based on microsatellite analysis. Small Rumin. Res., 90, 101-108. https://doi.org/10.1016/j.smallrumres.2010.02.005

Pulina, G., Avondo, M., Molle, G., Francesconi, A.H.D., Atzori, A.S. \& Cannas, A., 2013. Models for estimating feed intake in small ruminants. R. Bras. Zootec., 42, 675-690. http://dx.doi.org/10.1590/S1516-35982013000900010 
Qwabe, S.O., van Marle-Köster, E. \& Visser, C., 2013. Genetic diversity and population structure of the endangered Namaqua Afrikaner sheep. Trop. Anim. Health Prod., 45, 511-516. https://doi.org/10.1007/s11250-012-0250-x

Red Meat Producers Organisation, 2019. http://www.rpo.co.za/information-centre/absa/weekly-prices/ Accessed 1 September 2019.

SAS Institute, 2006. SAS/Stat user's guide version 9, volume 3.SAS Institute, Inc, SAS Campus Drive, Cary, North Carolina 27513.

Schanbacher, B.D., Crouse, J.D. \& Ferrell, C.L., 1980. Testosterone influences on growth, performance, carcass characteristics and composition of young market lambs. J. Anim. Sci., 51, 685-691. https://doi.org/10.2527/jas1980.513685x

Shadnoush, G.R., Alikhani, M., Rahmani, H.R., Edriss, M.A., Kamalzadeh, A. \& Zahedifar, M., 2011. Effects of restricted feeding and re-feeding in growing lambs: intake, growth and body organs development. J. Anim. Vet. Adv., 10, 280-285.

Sheridan, R., Ferreira, A.V. \& Hoffman, L.C., 2003. Production efficiency of South African Mutton Merino lambs and Boer goat kids receiving either a low or a high energy feedlot diet. Small Rumin. Res., 50, 75-82. https://doi.org/10.1016/S0921-4488(03)00109-3

Siebrits, F.K., Kemm, E.H., Ras, M.N. \& Barnes, P.M., 1986. Protein deposition in pigs as influenced by sex, type and livemass. 1. The pattern and composition of protein deposition. S. Afr. J. Anim. Sci., 16, 23-27.

Strydom, P.E., Frylinck, L., Van der Westhuizen, J. \& Burrow, H.M., 2008. Growth performance, feed efficiency and carcass and meat quality of tropically adapted breed types from different farming systems in South Africa. Aust. J. Exp. Agric., 48, 599-607. https://doi.org/10.1071/EA06057

Terblanche, T., 2013. An economic analysis of an intensive sheep production system on cultivated pastures in South Africa, incorporating creep feeding and accelerated breeding practices. MTech. Agric. thesis Nelson Mandela Metropolitan University, South Africa.

Tshabalala, P.A., Strydom, P.E., Webb, E.C. \& De Kock, H.L., 2003. Meat quality of designated South African indigenous goat and sheep breeds. Meat Sci., 65, 563-570. https://doi.org/10.1016/S0309-1740(02)00249-8

Van der Merwe, D.A., Brand, T.S. \& Hoffman, L.C. 2019a. Modelling subcutaneous fat deposition in growing South African lambs. Proc. of 65th Int. Con. Meat Sci. Tech., pp. 656-657.

Van der Merwe, D.A., Brand, T.S. \& Hoffman, L.C., 2019b. Application of growth models to different sheep breed types in South Africa. Small Rumin. Res., 178, 70-78. https://doi.org/10.1016/j.smallrumres.2019.08.002

Van Wyk, J.B., Fair, M.D. \& Cloete, S.W.P., 2003. Revised models and genetic parameter estimates for production and reproduction traits in the Elsenburg Dormer sheep stud. S. Afr. J. Anim. Sci., 33, $213-222$. http://dx.doi.org/10.4314/sajas.v33i4.3777 